\title{
Synergy and Corporatism in El Mirador and Atitlan, Comarga
}

"We don't need 3X1 or the paisanos, we live here. We have our own ideas about what this town needs," insisted Lydia, member of the Patron Saint Festival Association and resident of Atitlan, Comarga. After a contentious year, residents of Atitlan had enough of paisanos' directives to pay for a public goods project they had no part in choosing and of challenges to the autonomy of the Patronato as the representative voice of the community. The migrant leadership of Club Atitlan had formed an alliance with the municipal government and shut out local residents from meaningful participation in the transnational partnership that organized public goods projects through the $3 \mathrm{x} 1$ Program, although the migrant-state partners demanded that the Patronato contribute resources. The corporatist coproduction partnership crowded out key community stakeholders from deliberation in the selection and coordination of a $3 \times 1$ pavement project that was neither a priority for the homeowners nor something they wanted to help finance. As a result, state-society and paisano-resident relations became contentious, and residents mobilized political support for the opposition party to punish the incumbent for privileging the paisanos' remittances and voices over those who lived in the town and were represented by the Patronato.

Why were social relations between migrants and nonmigrants in Atitlan contentious? Why were residents treated as clients of the migrants and the state and not included in the coproduction process as meaningful contributors? In Atitlan, members of the hometown association lacked social bridging ties to key community stakeholders and they did not attempt to create them as they prioritized social status and political power over social solidarity with local residents. By contrast, in another locality in Comarga called El Mirador, a migrant hometown 
association successfully coproduced several public goods projects with the same municipal government in the same period of time. What was different in the two partnerships was that paisanos of El Mirador were still socially embedded in the hometown community after living abroad in the United States for more than 15 years. Practices of cultural membership in the hometown community and extensive bonding and bridging ties to local residents, especially migrant returnees to El Mirador, led to high levels of community inclusion. Residents were equal partners in the transnational partnership and formed a new civic association to work directly with Comarga municipal officials on a cancha (recreational court), lienzo charro (rodeo ring), street and sidewalk construction, and pavement and drainage projects. El Mirador residents routinely had face-to-face contact with municipal officials and negotiated project selection and project planning with the directors of social development and public works in the ayuntamiento. Even though both clubs were formed at the same time and with the encouragement of the same mayor, and had similar levels of poverty, population size, and partisan attachments, the transnational partnerships were organized differently because migrants' membership in the social community of their respective hometowns diverged.

In this chapter, I explain how low levels of community inclusion, but high levels of government engagement, organized a corporatist transnational partnership that had important consequences for political activism and state-society relations in Atitlan. I also present the partnership case of El Mirador, a locality in the same municipality as Atitlan, but one in which migrant social embeddedness in the hometown community led to higher levels of community inclusion in the provision of public goods. The comparison of two cases of transnational coproduction, which holds local-state capacity and electoral incentives constant, allows me to isolate and trace the key role that hometown-paisano social relations have in determining the structure of partnerships, which produced different political outcomes in the two hometown settings.

\section{ATITLAN AND EL MIRADOR, COMARGA, JALISCO}

The municipality of Comarga is located four hours north of Guadalajara in the northern region of Jalisco in the Sierra Madre Occidental Mountains. The municipality borders Zacatecas to the northwest and southeast. In 2005, the population was approximately 18,000; however, like many municipalities in Mexico, Comarga lost a significant portion of the economically active population to the U.S. labor market. Between 2000 and 2010, the intensity of international migration increased and changed Comarga's classification from "medium" to "high." About 70 percent of the total population of Comarga lived in the country seat and the remaining citizens inhabited one of the four main localities. Differences in the provision of public goods between the county seat and Comarga's rural localities were striking. 
For example, before 2005, the last time that rural communities like Atitlan and El Mirado received a public works project was when the PRI extended the electrical grid and potable water service in 1976.

According to official population statistics, Comarga is a middle-income municipality with a "medium" level of poverty, but the localities in Comarga are poorer. ${ }^{2}$ In 2005, residents who lived on the outskirts of town lacked access to essential public goods such as drainage and sanitation. In both Atitlan and El Mirador about 8 percent of the population was illiterate. Many nonmigrant households had dirt floors and no plumbing in the home. Municipal administrations collected land taxes, license and water usage fees, and relied on revenue transfers from the state and federal governments to finance public works. But how mayors distributed those resources earmarked for public spending was entirely at the discretion of municipal officials. In Comarga, most mayors focused public resources in the county seat where the majority of the population resided. This decision left many households who lived in localities outside the town center to finance public goods on their own, often with remittance resources, which was the case in many municipalities across Mexico. ${ }^{3}$

El Mirador and Atitlan were two very similar localities in Comarga. In the wake of the economic crisis and drought of the 1980 os and 1990s, many people left the two localities for the U.S. in search of job opportunities. They settled mostly in Texas, Oregon, California, Indiana, and Illinois. In 2000, about 15 percent of households had a member of the household living in the U.S. and between 5 and 1o percent regularly received remittances, although these households were more concentrated in the localities than the county seat. Some migrant households used a portion of remittance income to finance indoor plumbing and to build water wells because they did not have access to the public potable water system. Both locales had similar levels of emigration, household remittances, and public goods provision. El Mirador and Atitlan also had similar levels of poverty according to the Mexican Census's marginalization index and population size. In terms of sociodemographic characteristics, the two localities were very similar, although El Mirador was more remote and higher up in the mountains than Atitlan.

Both locales were also supporters of the PAN political party and voters had cast their ballots overwhelmingly for the PAN incumbent since the party's first municipal victory against the PRI in 1992. In every subsequent election, the PAN won by double-digit margins. But in the 2005, 2008, and 2011 elections, PRI candidates made serious inroads and wrested votes away from the PAN, mostly in the county seat. Since the early 200os, localities like El Mirador and Atitlan had become even more important political districts as the PAN incumbent relied on their core supporters turning out to vote in increasingly competitive elections. In 2005, Pepe Coronado won the mayorship by a razor-thin margin against a popular PRI candidate, which put the PAN on the defensive for the first time since the early 199os. Pepe made public works provision a central component of his campaign platform, 
especially in localities like Atitlan where he was born. After he won the election he put these plans into action and identified paisanos in the U.S. with remittance resources as central to the achievement of this goal. Social spending through the 3X1 Program was a political strategy to supply loyal supporters with public goods and encouraged their continued support for the PAN.

\section{LEARNING ABOUT THE 3X1 PROGRAM \\ FROM MUNICIPAL NEIGHBORS AND JALISCO \\ STATE OUTREACH}

The dissemination of information from Comarga's mayor and nearby political officials was integral to Pepe's exposure to the $3 \times 1$ Program and eventual participation. When Pepe observed several new public works projects in a nearby municipality, he was curious how the mayor-whom he believed worked with a similar budget and population size as Comarga-had the requisite public resources to provide so many new projects in such a short amount of time. When he asked the mayor in the Zacatecan municipality about the increase in public service delivery, officials told Pepe about their participation in the 3x1 Program and explained to him how a group of paisanos from their municipality collaborated on public projects. Members of the mayor's administration took Pepe on a tour of the public works projects they had completed throughout the town. Since Comarga had a significant population of paisanos in the U.S., Pepe was motivated to partner with them on projects and set out to expand the spending capacity of his administration through participation in the $3 \times 1$ Program.

The entrepreneurial Panista mayor contacted state-level officials in Guadalajara, the Jalisco state capital, to learn more about the 3x1 Program and how the state helped mayors locate and contact their paisanos in the U.S. It was in his correspondence with officials of the PAN governor's office where Pepe learned about the Office of Migrant Affairs, an administrative unit of the state that kept organized records of emigrants from the state of Jalisco who were in the U.S. With the support of the Migrant Affairs Office, Pepe's administration identified paisanos from Comarga across the U.S. Since the Migrant Affairs Office registered migrants in the U.S. when they visited the Mexican consulate, they supplied the Comarga municipal administration with paisanos' contact information. Pepe's new administration identified a few U.S. cities where the majority of Comarga paisanos lived, reached out to them, and organized face-to-face meetings with them in 2005 .

Pepe and members of his administration visited paisanos from Comarga across the U.S. in one of his first activities after taking office. Although he was not successful in every meeting, he convinced migrants from different localities in Comarga to form a club. Two of the HTAs created during that visit were Club Atitlan and Club El Mirador. Information about the 3x1 Program and contact information of paisanos 
abroad allowed the mayor to recruit paisanos into a transnational partnership for public goods provision as political competition was heating up in Comarga.

\section{FORMATION OF CLUB ATITLAN}

Emilio was born in Atitlan and crossed into the U.S. with his mother when he was a newborn. She traveled alone to Texas after she separated from Emilio's father. Coming to the U.S. with a new baby and not much else, she returned to Atitlan after a few short months and reconciled with her husband when it became too hard to support herself and the baby in the U.S. Emilio spent the first 13 years of his life in Atitlan. When he was in elementary school in the 1970s, children his age attended school for half-days because the school building only had a few rooms for instruction. Younger kids went to school in the morning and older graders in the afternoons. Emilio never finished his primary education. "I was never that good in school. I got bored even though we were only there half the day! I much preferred being out in the open in the fields with my father," he said.

After Emilio's father died unexpectedly, his mother and siblings left Atitlan and immigrated again to the U.S. She did not believe she could take care of her family subsisting on the land on her own and so with most of her family had gone to the U.S. This time she went to California where her uncle lived. He found her a job in the agricultural fields of Fresno County where he worked. At the age of 13, Emilio worked with his mother in the fields and helped support the family. When his siblings were older and the family more settled in California, Emilio left and moved to Texas where many other paisanos from Comarga lived. He had grown tired of agricultural work and wanted to try something different. An old neighbor from Atitlan lived in San Antonio and he convinced Emilio to move there. Shortly after he moved to San Antonio he opened a small abarrote (convenience store), met his wife, and together they started a family in Texas.

It was in his store where Emilio was reunited with Esme. After more than 20 years, the two Atitlan natives recognized each other, and during their initial small talk discovered they had attended the same primary school. After a brief courtship, Esme and Emilio married. They had three children together, all born in the U.S., which they said contributed to their permanent settlement in Texas. Both Esme and Emilio became proficient English speakers and practiced with their children in the evenings. By the time I met the Atitlan natives in 2009 in Comarga, they described themselves as "Mexican American." While they had deep roots to Atitlan, they also had made the U.S. their home and had become accustomed to life in San Antonio. In many ways, Emilio and Esme had Americanized and they were proud to have done so. They cheered for their son at high school football games and celebrated American holidays with their non-Mexican neighbors as well as their hometown friends. 
When Emilio, Esme, and three other migrant families from Atitlan met with Pepe and the directors of social development and communications who accompanied the mayor on his U.S. voyage, Pepe's desires to modernize Atitlan resonated immediately with the paisanos. Emilio and Esme spoke at length about the poor quality of Atitlan's roads, the lack of a recreation area, and other provisions, which they thought the residents of Atitlan needed. Emilio said he told the mayor that Atitlan was "not beautiful" and when he recalled his hometown he "felt sorry" for the people who lived there who did not have access to the same kinds of services that they had in San Antonio. It was not difficult to convince the paisanos in the meeting to form a club and partner with the mayor on projects through the 3x1 Program.

Paisanos from Atitlan who lived in San Antonio described Emilio as the "natural leader" of the group and they unanimously agreed he should be the club leader after the municipal officials returned to Comarga. Four families from Atitlan that lived in San Antonio joined the club and they recruited some of their family members to join who had recently moved to northern California and Wisconsin for more lucrative jobs. At the meeting with the Comarga administration, the mayor requested that the first project they work on together was a concrete vehicle bridge that would connect the east and west sides of Atitlan. Members of the club were ecstatic about the project proposal. Half of the families had been born on the west side of the community and knew what a hassle it had been to cross the wooden footbridge during the rainy season. The project was personal to the members of Club Atitlan. Before they had even started the project, they were excited that they would be responsible for building a bridge for the hometown.

\section{THE CONCRETE VEHICLE BRIDGE PROJECT}

The river that ran through the town of Atitlan prevented about a third of residents from access to the road that provided the main route into the county seat. Since Atitlan only had one abarrote, residents needed to cross the river to get to the main markets in Comarga. Residents reported that they had expressed the need for a reliable vehicle bridge for 20 years given how treacherous it was to cross the river during the rainy season. When I asked residents in Atitlan what they thought was the most important issue that faced the Atitlan community, residents said it was, before 2006, the bridge. Residents recounted how donkeys drowned, boats capsized, and neighbors needed to be rescued when their cars got stuck in the muds of the riverbed.

Pepe's parents were both born in the west side of Atitlan. So when he campaigned in Atitlan during the election, and residents broached the topic of the vehicle bridge, he promised them that if they raised matching funds to contribute to the project, he would "find the money through a program" and build the vehicle 


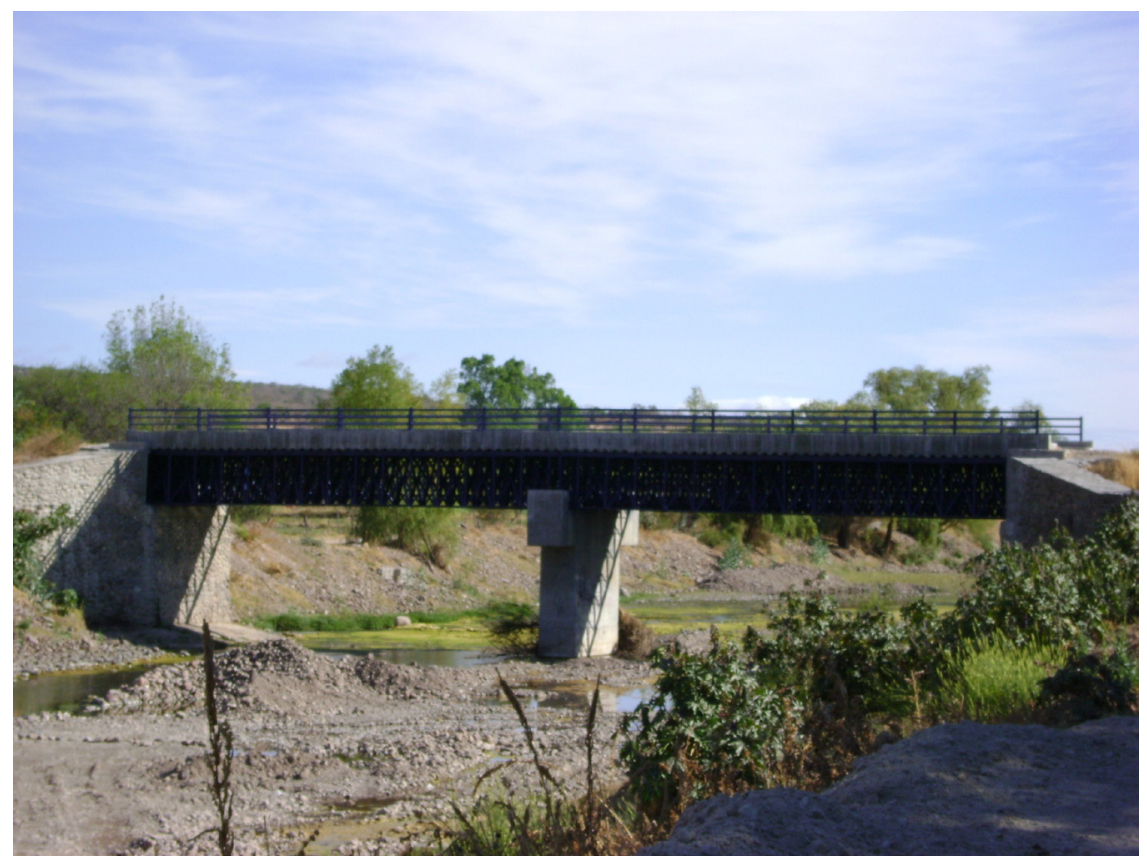

FIGURE 4. Vehicle bridge project completed through 3x1 Program in Atitlan, Jalisco. Photo by author.

bridge for Atitlan. After he heard about the 3x1 Program from the nearby mayor in Zacatecas, Pepe saw how he could make good on his promise to the local residents. He got the idea to ask paisanos from Atitlan to form a club, raise money, and help the municipality build the bridge with matching funds from state and federal government. The group of migrants from Atitlan initially formed to help build this vehicle bridge in their hometown.

Citizens, migrant paisanos, and the municipal government all contributed funds and together they built a vehicle bridge that connected east and west Atitlan. Residents of Atitlan had worked hard collecting donations, hosting raffles, and sponsoring dinners to fundraise their portion of the budget. They had formed a bridge committee that worked alongside the town Patronato, the patron saint festival committee, to raise their contribution. ${ }^{4}$ The involvement of the community residents was unknown to the migrant club, however. Since Emilio and Esme had not visited Atitlan in recent years and did not know many current residents, they did not know the extent of the town's effort and financial contribution to the bridge project. Beyond four migrant families in the community that the San Antonio migrants kept in touch with, neither Emilio nor other club members knew many of the people in the hometown since most of their families had rejoined them in 
the U.S.. While many migrants from Atitlan kept a house in the community, the houses stayed vacant but for a few days of the year when they visited.

Initially, the bridge project felt like a victory for the Patronato, residents of the west side of Atitlan, and members of the bridge committee who worked together to fundraise and make a contribution to the project. During the ribbon-cutting ceremony for the bridge in 2006, the mayor publicly thanked the paisanos for building the bridge in front of the whole town but said nothing about contributions from the Patronato or the bridge committee. He said that the bridge project was made possible by the "sacrifice" of the paisanos who left their hometown of Atitlan, but still cared for "nuestro pueblo" to build the residents a bridge. Excluding residents from public praise in favor of the migrant club was a serious misstep that generated confusion among the townspeople. The mayor's public praise for the HTA and the exclusion of their contributions upset locals involved in the bridge project who had spent time, energy, and resources fundraising with the Patronato. Atitlan resident Don Nel explained his reaction to the bridge ribbon-cutting ceremony:

I have personally asked each and every mayor for the bridge for 20 years. When I asked this mayor, he said he knew of a new program where we can get the money we need to build the bridge. We got together in the town and formed a bridge committee and raised money with the Patronato to help pay. Why the migrants are getting the credit for the bridge I do not understand. But this is typical. No one cares about us out here. ${ }^{5}$

Many residents who attended the bridge ceremony were initially confused about the mayor's public focus on the paisanos for the bridge project. But confusion eventually gave way to scorn as coproduction projects continued and Emilio presumed a position of leadership and authority in Atitlan, a town he had not lived in for decades.

When I asked about the calculus for public praise of the HTA and omission of the town's contributions at the ribbon-cutting ceremony, the mayor explained his political rationale. He wanted his and future Comarga administrations to implement many coproduction projects, and he identified the 3x1 Program as the way to make the municipal budget go further. Since the municipality only had to match 25 percent of the total cost of projects, he knew they could complete several more, albeit small public works projects in Atitlan, if they kept working with the paisanos. He wanted the people of Atitlan to realize the migrants enabled access to state and federal resources that made the bridge project possible through the 3x1 Program. Public acknowledgment of the migrants' contribution, he thought, would go a long way to encourage the club to continue participating in $3 \times 1$ projects and ingratiate Emilio to the residents of Atitlan. He had not intended to make the people of the town feel excluded.

Pepe assumed a level of familiarity and trust between himself and the residents of Atitlan because he, too, was raised in the town. He was friendly with many of the 
community leaders, especially Daniel, who was the leader of the Patronato and his second cousin. He was well liked in Atitlan, even popular among the residents, and after many casual conversations with community members it was clear that they respected him and Pepe had earned their vote. However, Pepe rationalized that because locals "knew him" and "his character" and his parents were from Atitlan, public praise of the paisanos at the ceremony was nothing more than an overture and his platitudes toward the migrants would help the citizens of Atitlan become beneficiaries of more projects in the end.

\section{DEPLETION OF BONDING AND BRIDGING TIES IN THE ATITLAN SOCIAL BASE}

While Pepe had extensive social ties throughout the Atitlan community, the mayor did not appreciate that migrant members of the HTA were not as socially embedded in Atitlan as in other localities where he helped form HTAs such as El Mirador. The mayor and the club leader both thought residents would applaud them for the completion of the bridge. After all, the bridge was an overwhelmingly popular project that residents wanted for years and it improved the quality of life for residents who lived on the west side of town. But instead of valuing the residents and the Patronato as equal partners and contributors, political officials and the paisanos had treated the residents of Atitlan as beneficiaries. Pepe took for granted that residents supported him enough that they would not interpret his lack of recognition of their contributions as a slight. Emilio and the migrant club members also assumed residents would credit the club for the provision of the bridge and that they would thank them when they visited the town. In reality, Emilio's physical separation from Atitlan eroded his social ties to residents, but it also meant he had limited information about social relations and what public goods the majority of local citizens wanted in the hometown. Emigration and many years living and working in the U.S. left Emilio out of touch with social life in Atitlan.

Aside from the four migrant families whose relatives lived in San Antonio, Emilio and Esme lacked bonding ties with anyone else in the town. While other paisano club members reported they still kept in touch with some siblings back home and had a few acquaintances from elementary school whom they chatted with occasionally on social media, most of the club members' families had moved to the U.S. and shifted their social life and contacts to people in their destination cities. By 2006, paisanos affiliated with Club Atitlan had few connections to nonmigrant residents outside of their immediate social circle of migrant families involved with the club in Texas and California. Bridging ties were also nonexistent. Neither Emilio nor Esme had bridging ties to members of the Patronato, the de facto governing body of Atitlan, nor did either of them try to construct meaningful social relationships with Daniel or any others who were considered leaders of the Patronato. 
The Patronato by all accounts was the most important social institution in the locality. Rather than recruit the Patronato into discussions about 3X1 projects or even ask the members of the social group about their perceptions of residents' desires for public projects in Atitlan, Emilio, Esme, and paisanos in the club thought they knew what the hometown needed and they did not solicit input from locals. In fact, they believed their experiences in the U.S. gave them a privileged perspective that the local townspeople could benefit from. They wanted to improve the image of the hometown and thought 3X1 projects should make it "more beautiful" and "more modern." Furthermore, Emilio had aspirations to become a leader of Atitlan and use his experiences in the U.S. to bring "prosperity" and "modernization" to his hometown.

Quickly, Emilio developed a reputation in the town as arrogant, a sentiment shared by most of the town's nonmigrant households. Residents did not have many opportunities to give him the benefit of the doubt since they only saw him in town for the bridge ribbon-cutting ceremony and at the fiesta patronal. Some residents thought the bridge project had inflated his ego. When Daniel and his wife, Lydia, chatted with Emilio after the bridge project, they said they approached him as an equal and told him they believed together they could accomplish many projects for Atitlan. Unfortunately, they left with an unfavorable impression. They said he seemed "full of himself" (ser muy creído; lleno de sí mismo) and thought he was better than them because he lived in San Antonio and they lived in rural Atitlan. Lydia imitated how he walked with a puffed-out chest around Atitlan like he was the town's "benefactor," even though it was known to everyone in Atitlan that festival funds subsidized the bridge project and the bridge committee raised funds for the project too. Members of the bridge committee, including Don Nel, recalled that when Emilio introduced himself he said he was the "president" of the migrant club that "built the bridge in the town." This rubbed Don Nel the wrong way because he was the head of the bridge committee. Emilio did not even know who he was or how he had been a vocal proponent of the bridge for decades. In short, Emilio and Esme were no longer socially embedded in the community and lacked both bonding and bridging ties in the social base of the hometown. When Emilio presented himself and the paisanos as the benefactors of the bridge project, some residents felt annoyed and it made others feel defensive about the contributions they made to the bridge project.

Emilio's interpretation of Atitlenses as clients of the paisano club was rejected by the Patronato. Members of the Patronato were elected by residents of the town and saw themselves as the leaders of the town who represented residents' interests. Even though their central activity was to organize the fiesta patronal and care for the town's festival resources, the Patronato members knew all the members of the community and frequently discussed problems in the town at their meetings. Residents, they said, were not interested in recreation areas and basketball courts (championed by Emilio) because they had more pressing needs. 
First, residents wanted street lamps for corners of the town where "drunks" (los borrachos) camped out late in the evenings. Atitlan had no street lamps and it became pitch black at night, which made it difficult and sometimes dangerous for people to navigate back to their homes. Residents wanted street lamps because they thought better lighting would discourage people from congregating in dark corners and harassing residents. Second, parents of school-age children wanted to build sidewalks along the main road into Atitlan. Schoolchildren in Atitlan attended elementary and high school in the county seat and the bus dropped them off on Route 23. Children and parents had to walk down the main road into town without sidewalks and where cars sped by, which made it unsafe. Finally, half the residents of Atitlan did not have access to the public drainage system and had to expel sanitation down a stone latrine that emptied into the river a few miles downstream from the town, which often backed up. Improvements in drainage access to households in Atitlan was a public goods priority in Atitlan that most residents supported. None of these projects was proposed to Atitlenses and the paisanos were more interested in making the hometown they remember "beautiful" than either listening to or solving the problems that residents who lived in the town confronted daily.

\section{COMMUNITY EXCLUSION AND CONFLICT IN THE ATITLAN SOCIAL BASE}

During the patron saint festival, Emilio met with the newly elected PAN mayor, Antonio, who succeeded Pepe and they discussed future coproduction projects for his term. Emilio and Antonio decided together they wanted to pave streets in the town to make Atitlan "more modern." Eager to continue the partnership with the HTA forged by his predecessor, the mayor agreed to the street pavement project and worked with his administration to draw up technical plans and secure approval through the 3x1 Program. In the visit, Emilio proposed to the mayor that since migrants "visit only three or four days a year" residents of Atitlan should be required to "pay their fair share." The mayor agreed to this and told me he rationalized the requirement because it decreased the total cost of the project to the migrants and municipality. For Antonio, this was an efficiency gain and meant they could do more projects in Comarga if Atitlenses contributed resources. The two men decided to hold a meeting in Atitlan with the Patronato where they explained they would fund a road pavement project for the residents of Atitlan.

The director of social development, Jorge, invited Atitlan residents to a town hall-style meeting. At the meeting he sat at a table with Emilio and the town delegate, Ramon, at the front of the room while members of the Patronato and residents sat on benches or stood along the walls. Ramon informed them that after the success of the bridge project through the 3x1 Program, the migrant club and the municipality would begin to pave the three main crossroads of Atitlan. He told 
citizens that to complete the project each household would have to contribute a small share. Club Atitlan and the representative of the municipal government presented themselves as partners working together for the betterment of the Atitlan community. Emilio told those in attendance that his club would work with the mayor and with Ramon to make Atitlan a beautiful town that they could all be proud of. He invoked the language of community and encouraged the residents to "work together" to help make the town a better place. This overture did not resonate with community residents and members of the Patronato in attendance. Many residents were upset that the paisanos and municipal officials unilaterally decided they should have to pay for a project they had no say in choosing.

At the meeting, many residents in attendance were still confused about what the $3 \times 1$ Program was, who made up the HTA, and why the HTA and municipal officials told them they had to contribute funds to the $3 \mathrm{x} 1$ pavement project. The municipal administration and Emilio had never explained the 3x1 Program to residents. There was a great deal of information asymmetry between residents and the Patronato, on the one hand, and municipal officials and Emilio, on the other. Some residents were hearing about the 3x1 Program for the first time. Don Juan, a longtime resident, asked the delegate, Ramon: "If this is a federal program, why are you telling us we should be paying? I'm not paying for this." Others had heard about the program but did not know who Emilio was and did not understand what involvement the paisano club had in the federal program. Other residents began to focus on the pavement project: who decided it and how much would they need to pay? Residents wanted to know exactly what their money would pay for. As residents tried to figure out what was going on and whispered their questions to each other, Ramon, Jorge, and Emilio attempted to speak over the residents.

Daniel, president of the Patronato, stood up and moved to the front of the room. He stated he would not commit Patronato resources to the pavement project before he met with members of the association to discuss it. They would not give the paisanos and the director any decision on the spot at the meeting. Other residents were also vocal about their opposition to the project because they had never been consulted about project selection and did not believe that they should have to contribute resources to a project of a federal program. Tension between residents and paisanos escalated and the meeting adjourned without a clear resolution. After the meeting, Emilio asked me to go around town to people's houses and do damage control. He wanted me to speak to my contacts and friends in the town and persuade them to support the club. I did chat with people around town after the meeting, but I listened to their concerns. I did not attempt to influence residents' opinions of Emilio, Club Atitlan, or the 3x1 Program despite Emilio's encouragement that I do so.

In the follow-up meeting of the Patronato to discuss the 3x1 pavement project that occurred after Emilio drove back to San Antonio, members were openly frustrated that the paisanos and the political officials had formed an "alliance." "Did you 
see how they sat up their like they were the kings?" Carla said. "They think we will just do whatever they say we should do," said Don Juan, exasperated. At the close of the meeting to discuss the pavement project, the Patronato members arrived at a consensus. Patronato members decided they did not want "outsiders" (fuereños, gente de afuera) to determine what kinds of projects residents needed in Atitlan. At several points in the discussion, members of Patronato invoked territoriality and an "us/them" dichotomy in reference to locals who "lived here" and paisanos who "lived there." Members were resolute. Money raised by the Patronato for the annual festival should be decided by the people who live in the town and resources would not be earmarked for public projects sponsored by the 3x1 Program.

While initially frustrated with the tone and presentation of the 3x1 Program, the pavement project, and Club Atitlan's role in town affairs, some members said they appreciated what the paisanos were trying to do, but there was agreement that they had gone about it the wrong way. Moreover, longtime members of the Patronato were skittish about using festival funds for public projects because they tried it once before and it ended badly. The previous Patronato president used festival funds to help the local baseball team purchase new uniforms. However, after they donated the money, the team never purchased new uniforms. Some residents were upset with the Patronato and thought they should have known better than to get "scammed" (estafado). The Patronato worried that Atitlenses might lose trust in them if there was a repeat situation with the pavement project. At the close of the Patronato meeting, the members entrusted Daniel to reach out to the paisanos and Mayor Antonio's administration. He told them that they would only contribute Patronato resources if the majority of the townspeople agreed to it. They concluded that the best way forward was to survey the townspeople and make sure everyone was onboard with the pavement project in the spirit of community inclusion.

\section{PAISANOS' ABSENCE AND THE DIFFICULTY OF CROSS-BORDER COMMUNICATION}

The conflict continued for several months, and relations between paisanos and residents and residents and political officials continued to sour. Up to this point, political officials had pledged support to the migrant club in private, and in public they applauded their efforts and came to their defense. Community inclusion was low, but the paisano club had the full commitment and support of the municipal government that was eager to complete several $3 \mathrm{x} 1$ projects with the migrant club. Political officials wanted the completion of public goods projects to reflect positively on their administration. But the transnational partnership was perceived by most local residents as an alliance between the local government and the paisanos because residents' involvement in the coproduction process was minimal. Additionally, as the paisanos' local reputation became viewed as increasingly 
exclusionary and even bullying by some, Atitleneses' opinions of Antonio's PAN administration was also negatively affected. When municipal officials privileged Emilio's wishes, and by extension the members of Club Atitlan, over local residents' call to be part of the decision-making process, residents felt further alienated by their local government representatives. Since migrant and local officials had pressured the Patronato and residents to contribute financial resources to the pavement project, residents had become increasingly disenchanted and consternation grew in Atitlan.

Since Emilio was back in the U.S., communication between the migrant club, residents of Atitlan, and the mayor's office occurred via email. As many who use electronic mail know, this form of communication can lead to misinformation and misinterpretation of tone. This was certainly the case in the emails exchanged between Emilio, the mayor and officials in his administration, and Daniel. Part of the problem with this form of communication was that only Daniel received the emails because of his leadership position in the Patronato. Daniel forwarded the emails to other residents of the town, but because few residents had a computer with internet access in their home, most residents did not see the communications until he printed out the emails and brought them to Patronato meetings. To check email in Atitlan, residents had to use Doña Sofia's computer at the corner store, which used a dial-up connection, or they had to travel to an internet cafe in Comarga, eight kilometers away, and pay a fee.

Another problem with email for communication and conflict resolution was that Daniel did not check email as frequently as the paisanos in the U.S. He and Lydia both worked as schoolteachers in different municipalities nearby and they had two teenage sons of their own whom they were raising. By contrast, Emilio was semi-retired. He owned his abarrote, but he had employees to oversee the shop. He focused more time on the club and sent frequent updates about pavement project negotiations to the club listserv, Daniel, and municipal authorities. However, Daniel's slower than expected response times to Emilio's messages were misconstrued. Paisanos interpreted his silence as an attempt to stall the pavement project. Club members thought Daniel did not adequately appreciate the club's philanthropy. Emilio's nephew, for example, thought Daniel's silence suggested Atitlenses resented the paisanos' success in the U.S.

The paisanos wanted the townspeople to go along with their preferred projects and pay their small contribution "to make it fair" so that they could move on to the next 3X1 project, but within this ongoing conversation something deeper was taking place - a social rift between paisanos and nonmigrant residents of Atitlan. Paisanos spoke to each other over email and speculated that Atitlenses resented their patronage, were jealous of their success in the U.S., and blamed Daniel for not acquiescing to their demands. I was in Atitlan when Daniel received these emails, and because I regularly visited the internet café and was on the club's listserv, I read all the emails sent internally among the paisanos. In fact, I had read 
most of the emails before any of the local residents of Atitlan had read them and witnessed residents' first reaction to the emails when Daniel shared Emilio's messages with the townspeople in attendance at the Patronato meetings. The residents were, in short, appalled, and were quick to defend Daniel as the "true leader" and "voice of the people" of the town.

What club members in Texas failed to grasp was that the pavement project was not a priority in Atitlan and email was not a mode of everyday correspondence. The last straw came when Emilio and the brother of a local Atitlense man who lived in El Paso rhetorically questioned in a series of emails whether the Patronato really represented the "best interest" of the people of Atitlan. Paisanos in the U.S. began to call into question the need for the Patronato, which was the single most important social institution in Atitlan.

Club Atitlan and the municipal government of Comarga received approval for the street and sidewalk pavement projects from the 3x1 Program and all the funds from the coproduction partners (municipal, state, and federal governments and migrant club) had been deposited in the municipal treasury. Members of the migrant club did not understand why the townspeople refused to contribute a share to the $3 \mathrm{x} 1$ project via the Patronato. Emilio wrote a contentious letter to Daniel and asked, "What was the function of the Patronato . . . was it to punish the paisanos, our donations, and our sacrifices? . . What was the role of the Patronato after all?" ${ }^{\circ}$ One of Emilio's nieces, located in Texas, openly questioned the role of the Patronato: "Why was the Patronato punishing [them]? All [they] wanted was to do good things for our town." Residents of Atitlan and leaders of the Patronato became increasingly worried that the HTA and their "allies" in the municipal government wanted to steal the Patronato's money. Patronato leadership was also distressed that paisanos invoked membership in Atitlan and justified their demands for town contributions to the 3X1 pavement project. Paisanos had inserted themselves in the public affairs of Atitlan, questioned the purpose and role of the central social institution in town, attacked the integrity of their popular leader over email, and used the language of "nuestro pueblito" in an attempt to legitimate their role in decision-making in a town in which territorial residents regarded them increasingly as outsiders in response to their exclusionary practices with regard to coproduction activities.

\section{RESIDENTS SANCTION CLUB ATITLAN FROM PARTICIPATION IN TOWN AFFAIRS}

The Patronato decided to hold an emergency town hall meeting after the last slate of emails from Club Atitlan directed at Daniel. They invited everyone in the town to attend and gave everyone who wanted to an opportunity to speak their concerns. I was responsible for keeping the minutes of the meeting, which would then be relayed back to the paisanos. The meeting was standing room only. More than 
50 people attended and several others stood outside the double doors and listened to the discussion. No members of the HTA were present, but two former migrants whose brothers were members of the HTA came as representatives of the club. The Patronato treasurer, Angelica, began the meeting and she expressed what many locals had expressed to me in private and in their Patronato meetings:

I don't understand his motives [Emilio]. I saw him at City Hall talking with the officials, with Pepe, with Antonio, with Jorge. But he never came and talked to us directly. I am completely against releasing any funds to these people. We have never even seen his face before. Have you seen his face? [Asking the crowd] I am worried. What if something bad happens? Will the neighbors still have faith in the Patronato if something happens to their money? ... Who is he [Emilio]? Is he even Mexican anymore? He does not even live here and he wants to tell us what to do with the Patronato money? No.

Lydia, Daniel's wife agreed. She was also skeptical about why the paisanos wanted residents to pay for a federal program in the first place:

How much money does this club actually have? How do we know they ... are not holding out and making us pay? I saw those emails that Emilio sends Daniel and he says this is how much the citizens and the Patronato have to pay. They say this is a federal program. I know it is because I see signs in Jerez, in Tlatelnango, in Tepechitlan, 3x1 signs, and do they make those citizens pay? Who does he [Emilio] think he is? ... We live in this town. We know everyone and everyone knows us. Why don't we just go to all the neighbors and see what kinds of projects they would be interested in the Patronato supporting ... we don't need $3 \times 1$ or the paisanos ... we live here.

As the mood in the room shifted to resolution and residents said they were ready to take an informal vote about whether to engage in any further correspondence with the club, the brother of the migrant club members attempted to cast the club's contributions and intentions in a more favorable light. The residents proposed a motion to contribute some of the funds to the pavement project in solidarity with the paisanos but decided that they would tell the club that they needed to work together if they wanted to do any future projects. This was considered by many residents in attendance as a favorable neutral ground because they did not want to feud with the paisanos abroad.

At the close of the meeting, the Patronato decided to release half of the funds for the pavement project that was stipulated by the HTA and municipal government. By a show of hands, they agreed to donate complementary resources to the project to preserve peace. Residents characterized their contribution to the paisano project as a good faith effort that tried to restore paisano-hometown relations, but that did not fully give in to Club Atitlan's demands. Moving forward, though, residents overwhelmingly agreed that public works decisions would not be defined by the migrant club, but by the people of Atitlan who were represented by the Patronato and cared for the (town) festival funds. Daniel relayed the decision to the club in 
an email addressed to the paisanos of Club Atitlan, the current and former mayors of Comarga, the Atitlan delegate to the municipal government, and the directors of public works and social development.

In follow-up conversations with members of the HTA they expressed confusion with Daniel's response. They reported feeling "attacked" for their generosity by the hometowners, especially by Daniel who had become the de facto voice of Atitlense residents in cross-border communications. Some members of the HTA suggested they "withhold" funds for future coproduction projects unless the town contributed an equal share. Other members recommended Daniel be replaced as president of the Patronato. They wanted a local leader more aligned with club interests.

The events that unfolded after the completion of the bridge project between December 2008 and August 2012 exacerbated social divisions in Atitlan, especially between nonmigrant and migrant households that sided with the club. Because the HTA failed to solicit the input of the Patronato, a trusted association in the Atitlan community, and attempted to make decisions about public works projects on behalf of the people of Atitlan without consultation or inclusion in project deliberations, conflict ensued. Residents no longer recognized Emilio and Esme, and by extension members of the HTA, as members of Atitlan with the legitimate voice to make decisions on behalf of the town. Exclusion of the Patronato would not be tolerated by local residents and they decided to push back.

Club leaders neither engaged in meaningful repertoires of community membership after departure nor maintained bonding and bridging ties in the social base of the hometown that imbued them with the authority to speak on behalf of community residents with the mayor with regard to issues that concerned public life in Atitlan. Emilio and Esme did not participate in the social life of the community, except for a visit now and then. Other members of the HTA had not visited Atitlan in years. Their social base of support in the community was limited to a few migrant families in the town. Moreover, the migrant club did not attempt to forge a relationship with key stakeholders in the community (the Patronato) who were respected leaders of the community and who represented the community to the delegate and to the municipality. Whether it was intentional or not, paisanos' emails to each other and to Daniel demeaned his role as the leader of the Patronato, which was perceived by the residents of Atitlan as an affront.

The paisanos' emails were a frequent topic of conversation and gossip in town. When residents finally read printouts of the emails, some residents openly said that Emilio could no longer be trusted. Residents were open to being contributors to the coproduction process, but they wanted to be included as equal partners in deliberations about projects in their town. Residents including Don Nel, Don 
Juan, Angelica, Lydia, Sofia, and others could not understand why Emilio acted like he was the "presidente municipal" of Atitlan, when, in fact, he was their paisano. Being born in Atitlan and having gone to elementary school there neither endowed Emilio with more voice in public decision-making nor made him better than the people of Atitlan.

Emilio and migrant club members enjoyed the exclusive attention of local politicians. For Emilio, community inclusion meant financial contributions, not decision-making authority. Moreover, club members valued their direct access to the elected officials of Comarga and influence in decisions about town affairs. Many paisanos described how living in the U.S. helped them see the extent to which Atitlan lacked public goods. Immigrating to the U.S. revealed how deficient public goods provision was in Atitlan and they wanted to help make it a better place than they left it. But paisanos' affective ties and altruistic goals were not apparent to the residents of Atitlan, especially members of the Patronato. Residents who said they met Emilio and talked with him when he visited town described him as "boastful" (presumido) and "arrogant" (arrogante) and attributed these character traits to attitudinal changes brought about his emigrating to the U.S.

The transnational partnership, especially the completion of the bridge project, elevated Emilio's social status among the other paisanos in the club.7 Club members heaped praise on Emilio for his "leadership in Atitlan" and his "sacrifice." Emilio recognized the benefits that his cross-border participation had for his identity. He said, "Here (Atitlan) I am someone important. I have meetings with the mayor. I am trying to do something good. I represent the paisanos. But over there? In Texas? I just own a little store." Migrants from Atitlan hoped to use their social mobility to do something good for a town they loved from afar. But their attempts to reinsert themselves as a representative voice of the community as if they had never left was met with resistance. Members of the club were no longer perceived to be part of the social base of the Atitlan community and they did not universally represent residents' interests. Migrants did not have the authority to charge local residents for $3 \mathrm{x} 1$ coproduction projects. Atitlan residents were involved in their community so when they were effectively excluded from decision-making about projects that both affected their lives and required a financial contribution from them, they in turn mobilized to resist outside influence from migrants who were perceived as allied with the local government. Nonmigrant citizens who were active in the social and political life of the hometown struggled for the same access, attention, and influence that migrants had in their transnational partnership with the municipal government. When they perceived themselves to be a disadvantaged group in their own town, they decided to compete for equality through collective action. They were galvanized to take concerted action when Club Atitlan "schemed" to dislodge Daniel as leader of the Patronato and replace him with the brother of a migrant club member. 


\section{CLIENTELISTIC BREAKDOWN? THE COLLECTIVE}

\section{RESPONSE OF MOBILIZED RESIDENTS OF ATITLAN}

After several weeks of transnational discord between residents and paisanos in San Antonio, communications between the migrant club and the Patronato ceased. Residents of Atitlan continued to go about daily life and were under the impression that after contributing some funds to the pavement project, they had reached an understanding with the paisanos that future $3 \mathrm{X} 1$ projects would go through a process of collective decision-making in which residents would be equal, active participants in the selection and implementation of public goods projects. However, this is not how Emilio and other paisanos wanted to proceed. In club communications and meetings in San Antonio, Emilio and the paisanos decided that they would continue $3 \times 1$ projects in the hometown but needed new leadership in the Patronato in order to move forward with public projects and use part of the festival funds to do so. Emilio spearheaded an effort to get Ángel, a paisano's brother who farmed the family land, to run for president of the Patronato. The paisanos believed that once Daniel was no longer the leader of the Patronato, and by extension the town, and replaced with a migrant club ally, they would be able to complete many projects for Atitlan through the 3x1 Program and residents would see how important the paisanos were for the betterment of the hometown.

When Angelica, treasurer of the Patronato, heard that Ángel planned to challenge Daniel for the leadership role, she organized an informal meeting with all the heads of household in town with Ramon, the delegate, in attendance. Since Ángel had never been involved in public life before, some residents thought it was odd that he wanted to take on a leadership role out of the blue. And everyone liked the job that Daniel had done for the festival and thought he was very careful with the town's money. He had become even more respected when he was attacked by the paisanos and stood up to them for the people of the town. The Patronato's concern was not directed at Ángel, whom residents characterized as a "puppet" (titere de la $c l u b$ ), but rather at the paisanos, Emilio in particular, whom they suspected to be behind the scheme.

Although Angelica and other concerned residents of Atitlan did not know for sure, their suspicions were correct. Emilio, at the urging of club members, called Ángel and encouraged him to challenge Daniel for the position so that they could do more 3x1 projects for Atitlan with Patronato resources. He had attempted to circumvent Daniel, whom Emilio believed to be the main obstacle to the use of Patronato festival money for $3 \times 1$ projects. What Emilio and members of the club never fully understood throughout the entire debacle was that residents had urged Daniel to take the leadership position. He was a humble, popular resident of the town and was highly regarded. To attack Daniel felt like an attack on everyone.

Residents of Atitlan rallied behind the Patronato. Daniel told the migrant club that their efforts to bully the Patronato in Atitlan would no longer be tolerated. The residents thanked the paisanos for their support in the bridge and road pavement 
and sidewalk project. And while the paisanos were always welcomed to attend the fiesta patronal, additional efforts to be involved in public affairs were no longer welcomed. After a year of contentious discussion over email and in person, residents believed that the municipal government and the paisanos (especially Emilio) had schemed together to misappropriate the residents' Patronato funds for official use. Club Atitlan was informally sanctioned from participating in town affairs. Ángel and his family no longer came to Patronato meetings.

\section{CASE SUMMARY}

The local government privileged the support of the HTA over local residents because they wanted to continue participating in the 3x1 Program. They believed supplying public works through the matching grants program was a clever way to extend municipal resources in the outlying community. This strategy backfired and may have cost the PAN in the next election. Citizens in Atitlan banded together and backed the opposition PRI candidate, a move designed to punish the PAN incumbent for not listening to their concerns and prioritizing the interests of the HTA. It is difficult to know how much Atitlan's political mobilization contributed to the PAN's loss (PRI vote share increased 12 percent from the 2010 to 2013 elections), but this was the goal of Atitlan voters. They wanted to punish the PAN party for privileging the HTA's contributions over the townspeople's wants and needs. The PAN's vote share declined 19 percent across the municipality and the PRI won handedly in 2013; the margin of victory was 31 percent.

The HTA's inability to forge meaningful bridging ties with the Patronato, a group of community stakeholders well regarded in Atitlan, produced a more corporatist coproduction partnership. Even though residents of Atitlan made explicit requests to be part of project deliberations, they were excluded from meaningful participation but for the request for financial support. Club Atitlan's privileged access and alliance with the local government received the full engagement of the municipality. Both PAN mayors were eager to cofinance coproduction projects through the $3 \times 1$ Program and worked hard to cultivate ties with the paisanos from Comarga in the U.S. ${ }^{8}$ Emilio and paisanos in the U.S. enjoyed the exclusive attention of elected officials that they thought elevated their social status in Atitlan. But the perceived alliance with municipal officials and exclusion of residents from meaningful involvement in the coproduction process worsened state-society relations between paisanos and residents and between residents and municipal officials.

After the election many local residents said they were "done dealing with politicians" and "none of them can be trusted." While the HTA felt connected to their hometown and wanted to express that attachment by supporting public goods, they did not expect that physical exit complicated the ability to use voice as if they had never left. Migrant membership status in the social collective was far more 
complex. Without a concerted effort to build meaningful bridges to social elites like Daniel, Don Nel, Don Juan, and other members of the Patronato inner circle, paisanos' cross-border public goods efforts made in the name of the community ultimately reinforced political inequalities between migrants and nonmigrants and introduced more distrust in the political process. As a result, the corporatist partnership between the HTA and the local government was short-lived and Club Atitlan became inactive when the PRI administration came into office. Citizens of Atitlan reported they were more disenchanted with municipal representatives and participated less in politics than before, even if their exclusion motivated shortterm political mobilization against the PAN party incumbent.

In Atitlan's more corporatist partnership, migrants' organized interests and links to a cooperative local government took precedence over competing societal interests of local residents. This arrangement produced two kinds of political effects. First, citizen exclusion compromised plural interest representation. In this context, citizens felt slighted and reacted by challenging coproduction decisions publicly, sanctioning the HTA, and making independent political demands on the state to be heard. Migrant-state corporatism in places with an active civil society increased the political participation of locals resulting from their exclusion in the coproduction process. Although I am reluctant to generalize from the Atitlan case alone as to the local conditions whereby citizen exclusion motivated political participation, one possibility is that places with latent or active social capital (e.g., an active social institution or citizen group like the Patronato) possess the social network ties of trust and reciprocity that can mobilize collective action more readily than places without.

Second, corporatist coproduction also caused citizens to retreat from public life and depressed political interest and engagement. Patterns of motivated inaction are often impelled by objective circumstances-people who know they cannot win often do not try. ${ }^{9}$ Corporatist transnational partnerships are, therefore, also likely to "crowd out" citizens' interest in and ability to use democratic channels to voice their preferences for public goods. Some residents, when they are excluded from meaningful participation in coproduction activities and perceive an alliance between the HTA and local government officials, stop trying to make their voices heard, which creates political disenchantment in some migrant hometown communities. Corporatist coproduction partnerships produce different and sometimes opposing effects on local civic and political participation. They also strain state-society relations depending on preexisting social and political institutions in the hometown.

\section{FORMATION OF CLUB EL MIRADOR}

Club El Mirador was a smaller, more tightly knit group than Club Atitlan. While they only had about six core families active in club affairs, they were a dedicated 
and energetic group of paisanos. Core members of the club engaged in circular migration in the 1980 s and 1990 s and traveled across the border together. The paisanos from El Mirador worked for the same employer year after year in Illinois and Indiana, saved money, and returned home for stretches before they returned to the U.S. Before the spouses of the group joined them in the U.S., the men lived together and saved their earnings in order to send more remittances home to their families. They were "like family." Not only had many of the men grown up together and emigrated at the same time, they supported each other in the U.S. so that they could better support their families who remained behind in El Mirador, Comarga.

Temporary, circular migration between El Mirador and the U.S. became more difficult in the early 2000 s when the U.S. government tightened border security in the wake of the terrorist attacks of 9/11. Paisanos from El Mirador without documents decided they would stay more permanently in the U.S. or risk capture at the border and detention by U.S. authorities. In response, Efrain, a core member of the club, decided it was the time to legalize. As soon as he met the residency requirements he naturalized and became a U.S. citizen. He then started the paperwork to petition for his spouse and children to join him in the U.S. While some of the men in the close-knit group of paisanos had acquired their green cards, others who migrated in the 1990 s had no path to citizenship and remained undocumented in the U.S. For some individuals who endured longer separations from their families, this was too much of a psychological burden to bear. When crossing the U.S. border became too difficult and dangerous, some paisanos returned home with their savings and stayed in El Mirador while others settled permanently in the Midwest after being rejoined by family members.

In the summer of 2005, Marco, Efrain, and Placido met with the PAN mayor of Comarga in Chicago. The paisanos traveled from Bolingbrook, Aurora, and Gary to have dinner with the political officials at their invitation. Pepe and members of his administration came to Chicago to tell the men about the 3x1 Program, but the migrants needed no introduction. Efrain and Placido knew of the program already. The small Zacatecas municipality of Tonitlan that borders El Mirador to the east had a migrant club that worked with the municipal government on several projects. The two communities were geographically and socially close. They shared resources (a water well) and hosted festivals together since both localities were the farthest away from their respective county seats. Friends in Tonitlan had told the paisanos about their collaborative partnership with the municipality long before the municipal officials met with the paisanos in the U.S.

The club from Tonitlan had recently made plans with the municipal government to build a rodeo ring (lienzo charro) with cofinancing from state and federal governments. When Pepe invited the paisanos from El Mirador to form their own club, they tentatively agreed on the condition that the first collaborative project would be a rodeo ring for El Mirador so that they could enjoy competitions with neighbors in Tonitlan. Charreada, a collection of events involving horseback 
riders (charros) and cattle inside a ring similar to a rodeo, was popular in the region. Several families in El Mirador practiced coleadero, a charrerada event that involved steer tailing, but they often had to travel long distances to compete because El Mirador was such a remote locality. The paisanos were excited about the rodeo project. If Tonitlan was also building a rodeo ring, they could have competitions and invite other coleadero teams to compete in El Mirador and Tonitlan. Comarga's mayor was not initially keen on using public resources for recreation projects in El Mirador since his administration's development plan focused more on security and the provision of public services. But he eventually acquiesced with the tacit agreement that future coproduction projects would be more focused on basic service provision such as water, electricity, drainage, and road pavement.

Marco, Efrain, and Placido discussed the paisano club for several weeks after Pepe and others from his administration returned to Comarga. The men decided Placido should be the president of the club and Efrain and Marco serve as the secretary and treasurer, respectively. The paisanos decided that no decisions would be made about the club or projects without taking it to the people of El Mirador first. Pepe was eager to propose the coproduction project to the state validation committee in his first year of office, but Placido did not want to start any project without discussing plans with the residents of El Mirador, especially return migrants with whom they remained in close contact. They planned to discuss the mayor's 3X1 proposal with residents in El Mirador over the Christmas holiday when many of the paisanos planned to return for a longer visit to their hometown.

\section{THE ROLE OF COMMUNITY MEMBERSHIP AND SOCIAL CAPITAL IN EL MIRADOR}

The people of El Mirador were a close-knit, poor community. In the rural town, everybody knew everybody. High up in the mountains about a 30-minute drive from the county seat, families in El Mirador relied on each other to solve local problems. Many families relied exclusively on remittances for income and those without migrant members abroad made ends meet growing tomatoes, beans, corn, and other staple crops. Many children who worked in the fields with their parents stopped attending school altogether after they finished their primary education.

In 2005, most streets in El Mirador were dirt roads, only half the houses had access to electricity, and many lacked access to indoor plumbing and sanitation. But the residents of El Mirador had found ways to make life a little easier by working together. The town made a collective decision that the north and south sides of town alternated use of the public water system every other day to make sure all had periodic access. Parents also took turns driving the children 30 minutes down the high mountain switchbacks so that they could take the bus the rest of the way to the secundaria. And migrant families that were dependent on remittances supported one another with extra food when money from the U.S. failed to arrive. 
This is what Placido said he missed the most when living in the U.S.: the people of El Mirador took care of each other even though no one had very much to give. Before making the difficult decision to settle permanently in the U.S. with his family, Placido always believed he would return to El Mirador. His decision to emigrate was not by choice, he explained, it was by necessity. "I thought I would be able to make enough in a few visits to come back and have enough money to fix the house and invest in the land. But it is not so easy in the U.S.," he explained, "I had to go back for years just to earn enough to buy land and care for my parents." Placido did not like living abroad. He had serious reservations about raising his sons in the big city and missed small-town, rural life in his community. His family had lived in El Mirador for many generations and were a respected family. His uncles helped pressure the PRI administration in the late 1970s to build a oneroom schoolhouse for the children of El Mirador, which was applauded by local residents. It was Placido's hope he would eventually return and be able to retire in El Mirador. Working with the municipal government was one way to help the people of El Mirador have a better life, which he reasoned would make the town a nice enough place that his sons might eventually return with him one day so long as economic conditions improved in Mexico.

During the Christmas holiday Efrain visited El Mirador. Efrain was the only migrant in Club El Mirador who had acquired a green card and could cross the U.S. border to visit the hometown without a serious hardship. From the U.S., the paisanos reached out to their families and friends and coordinated a day and time for the people of the town to meet and discuss the migrant club with Efrain. It was important, Placido recalls, for Francisco, a former migrant and local farmer, to be present at the meeting. Placido and Francisco migrated together and worked alongside each other for years. They stayed close friends even after Francisco returned to El Mirador. Unhappy in the U.S., Francisco returned to live with his family despite the continued difficulty making money selling crops in the region. Francisco said, "I never liked living in the U.S. It is just too different for me. I am a rural farm boy and so was my father. I had to come back."

Francisco was admired in El Mirador. He used his migration experience to help young men find a respected smuggler to cross the border and used his connections to help people find work even though he tried to dissuade many from leaving. He and his wife also checked in on migrant families to make sure they were doing all right. Francisco had become a leader in El Mirador even though he never thought of himself that way. Placido knew this and thought very highly of Francisco. If the town was going to have a migrant club that worked with the local government to provide public goods projects, everyone agreed that Francisco should be involved every step of the way.

Francisco was initially suspicious of the government's motives and questioned why migrants should be paying for public projects. But other paisanos in town for the holiday meeting with Efrain were more willing to give the partnership a 
chance. Augustin, a local farmer, recalled telling his neighbors that they should hear what the mayor could do for El Mirador using the 3x1 Program and only make a decision after they heard what he had to say. Augustin was also familiar with the public projects completed in nearby Tonitlan with paisanos through the 3xi Program and was curious what good could be brought to El Mirador through the same channels.

In the meeting, the residents agreed to support the migrant club and coproduction projects with municipal officials. They also decided to create a public works committee that was a local extension of Club El Mirador. The townspeople in attendance overwhelming supported Francisco to lead the committee with a few other volunteers. At the meeting and after further discussions throughout the holiday season, Club El Mirador and the newly formed Comite pro Obras alerted the mayor's office that they would propose the rodeo ring project to the 3x1 Program, register the migrant club, and begin fundraising their share of project costs in the U.S.

While Club El Mirador had only a few dedicated, core members, the network of migrants from Comarga and El Mirador was extensive. Paisanos from nearby Tonitlan also supported the club by attending their fundraising events in Chicago. Club Tonitlan was an older association and a member of the Zacatecan federation of migrant clubs in Chicago. They shared information with Efrain, Marco, and Placido about how other clubs successfully raised money, and Club El Mirador used the events of those clubs as a model. Club El Mirador's fundraising events in the U.S. started small, but eventually became grand affairs with paisanos from Comarga and beyond in attendance. The club hosted picnics with live music, held raffles, and took donations from attendees. And together with Club Tonitlan and other clubs in the Zacatecan federation they hosted fundraising charreada events in the U.S. using ticket and foods sales for coproduction projects. The dense networks of migrants from the region in the Chicagoland area and Club El Mirador's relationship with older, experienced clubs helped the club raise significant resources for El Mirador.

Placido and Club El Mirador quickly raised the 25 percent contribution for the first project and much more in the first few fundraising events. With Francisco leading the public works committee in El Mirador they held local meetings and visited the households in the town. They asked residents what kind of projects they would like to see the committee and the migrants propose to the municipal administration. By the following summer, they had drafted a list of several coproduction projects to work on in coordination with municipal government officials and the $3 \times 1$ Program.

Francisco increasingly served as the point of contact for the migrant club and the public works committee to the municipal government. While he initially had reservations about the partnership, he soon developed a relationship with Pepe and other members of his administration, especially the communications director 
and the director of public works. When he was in the county seat, he would stop in to the municipal government building (ayuntamiento) and check in on timelines, budgets, hiring labor, and materials for different 3x1 projects. Francisco then convened with other members of the public works committee and they made decisions together. When it was possible, they called Placido and other members of the migrant club on cell phones and everyone discussed coproduction projects together in the U.S. and Mexico on speakerphone.

In the coproduction partnership between Club El Mirador, Comarga's municipal administration, and the local public works committee, the partners completed several projects during Pepe's administration. Through the $3 \times 1$ Program and effective coordination between residents, paisanos, and government officials they built a rodeo ring, and recreation court, paved roads, and erected streetlights through the central part of town. When Mayor Antonio took office in 2007 the partnership continued through the municipal transition. Antonio said:

The club in El Mirador is so easy to work with. I told the paisanos in Atitlan to call Placido and ask what they are doing up there [in the mountains] because, honestly, they tell me what projects they want and then they work with the directors [of social development and public works] and do everything down here. The trouble I have with them is telling them "no"... We can't do so many projects because the other localities need attention too.

From the perspective of the municipal government, working on coproduction projects in El Mirador was efficient and effective.

While the mayor could not identify what about the partnership was "easier" than the partnership with paisanos in Atitlan, the answer was community inclusion in the coproduction process. Paisanos from El Mirador were still socially embedded in El Mirador and drew on their extensive bonding and bridging ties to include residents in all coproduction decisions to the extent that residents wanted to be involved. For many residents I spoke with, the transnational partnership was welcomed, but they did not have the time to participate. They were happy to have Francisco, the public works committee, and the paisanos make decisions on behalf of them because they were seen as members of the El Mirador community. In short, they were trusted to speak on behalf of the community residents.

The municipal government of Comarga identified the 3x1 Program as a way to expand their budget and provide public goods and services to localities in Comarga with high emigration. Pepe's PAN administration sought out the partnership with paisanos in the U.S. and helped create the clubs in 2005. Both PAN administrations brought the same level of engagement to the coproduction partnerships in Atitlan and El Mirador. In El Mirador, political officials provided technical planning, financial contributions, materials, labor, and contractors to support implementation of the vehicle bridge, rodeo ring, public lighting, and road pavement coproduction projects. The provision of public goods through coproduction and 
complementary financing from state and federal 3x1 Program partners became an effective strategy, the administration surmised, for public spending on local infrastructure. They wanted the transnational partnership with all the migrant groups to work. And in the increasingly competitive municipal elections in which the PRI gained electoral ground, capturing the support of citizens in traditional PAN strongholds by improving public infrastructure in their communities was a political strategy for victory.

\section{CASE COMPARISON: KEY ROLE OF MIGRANT SOCIAL EMBEDDEDNESS}

As the two cases show, transnational partnerships were organized differently in two communities in the same municipality. In Atitlan, the social base of the migrant network was limited to a few migrant families connected to the club. Club Atitlan lacked social ties to key stakeholders in the community and excluded the Patronato from the selection, planning, and implementation of $3 \times 1$ projects. They valued the Patronato only for the resources they maintained on behalf of the town. By contrast, in El Mirador, paisanos had a more extensive social base of support and included residents in the coproduction process. The involvement of Francisco, a key bridging tie to several households throughout the town, scaled up the participation of other residents and signaled to them that the transnational partnership reflected their interests and needs. Unlike Emilio, who represented the migrant club to the residents of Atitlan but did not participate in the social life of the hometown, paisanos from El Mirador practiced cultural repertoires and were more visible in the social life of their hometown even after they had emigrated abroad.

During the summers, Placido's children lived with their grandparents in El Mirador and traveled with Efrain when he visited for charreada events. The members of Marco's family who remained behind were neighbors of Augustin's, and Augustin volunteered for the public works committee after Marco encouraged him to do so. The active recruitment of Francisco, a leader in El Mirador and former migrant, and the maintenance of social solidarity through bonding and bridging ties in the hometown community explained why residents were more included in the coproduction process.

Club Atitlan's insistence that residents contribute financial resources for the street pavement project was rejected by the townspeople. They were willing and eager to contribute to the bridge project because they had a strong preference for it and had proposed the project to municipal officials across several different administrations. When the mayor supported Club Atitlan's decision to demand collection of complementary resources from the townspeople, residents perceived his support of the club in a negative light and thought the administration was out of touch with the needs of Atitlenses. The municipal administration went along with 
the club leader's demand because he did not want to jeopardize the transnational partnership, but he was either unaware of the social cost of the alliance with the paisano club or did not anticipate it would lead to a worsening of state-society relations and political opposition to the administration. Moreover, the club's decision to speak on behalf of the community in coproduction decisions without mutual recognition from hometown residents of their continued membership resulted in consternation and contestation in Atitlan.

The more synergetic partnership in El Mirador characterized by community inclusion and government engagement produced different social and political consequences than in Atitlan. The active involvement of residents in coproduction routinized interactions with political officials. Citizens of El Mirador started to believe that they could accomplish something by working together with the local government and the paisanos. Personal political efficacy was improved through the participation in the transnational partnership. Residents began to value democratic engagement because they witnessed firsthand how citizens' quality of life was improved through participatory action. Municipal officials visited El Mirador to prepare technical plans for projects and workers hired by the government showed up on time. Projects that the public works committee and Club El Mirador proposed to the government were completed in the town. Citizens were more empowered and checked the budget, observed the arrival of physical materials according to a predetermined timeline, and monitored workers to ensure quality and completion. When materials did not arrive on schedule, residents in El Mirador visited the ayuntamiento and let the officials know. On occasion, some residents volunteered their own labor to help the municipal contractors.

In short, the involvement of local residents produced more participatory action including the deliberation in project selection, information exchange, and more regular interactions between elected officials and ordinary citizens. And while occasionally citizens and officials did not agree and miscommunications occurred, both residents and citizens valued the partnership and recognized the benefits of negotiation. Municipal officials, for example, acknowledged the administration had to make concessions. Pepe explained:

We let them tell us what they need and we do it. Enrique [director of public works] and I can't use the whole budget in El Mirador because we have other localities, but we know Francisco and other people in the town well enough now that we can say, okay, this time we do this, but next time about how this project. Like with the water. We really need to extend the town's access to water, but that is a big project. The citizens wanted smaller projects first and then we decided to tackle the big water project in several phases.

The nature of the migrant social base in each town in the same municipality shaped the organization of the partnership and the corresponding changes in democratic participation and state-society relations. 


\section{SUMMARY}

Not all coproduction partnerships are organized such that many local citizens are included in the process or the local government is fully engaged. When one of these two organizing factors is variable, transnational partnerships are more likely to approximate fragmented or corporatist coproduction. In these two organizational forms, low citizen involvement based on weak social ties to migrant members of hometown clubs depresses the representativeness of local interests in public goods provision.

Coproduction partnerships in El Mirador and Atitlan in Comarga, Jalisco, were organized differently even though both clubs were created with the encouragement and support of the municipal PAN government. The difference in the nature of the partnership in the two communities can be traced to differences in the degree to which migrants remained embedded in the social base of the hometown. In El Mirador, migrants maintained more extensive bonding and bridging ties in the hometown and were inclusive of local residence participation in most aspects of coproduction project planning and implementation. As such, citizens worked closely with political officials and interactions between state and society in El Mirador became more routinized and productive. Citizens became more involved in everyday affairs of El Mirador and worked collaboratively with the local government to identify and execute public goods projects that improved local residents' quality of life. In turn, the responsiveness of elected officials to their constituents in a remote locality where residents seldom encountered, much less worked alongside, public officials in decision-making concerning public works also improved as a result of the synergy created by transnational coproduction.

By contrast, migrants from Atitlan were not well integrated into the social base of their hometown community after departure. They did not take steps to forge bridging ties with key stakeholders in the community even after community leaders requested to be more meaningfully involved in the coproduction process. Worried that they would alienate the paisanos from future 3x1 projects, the municipal government allied themselves with Club Atitlan, which further alienated citizens from coproduction. Despite short-term political mobilization in reaction to exclusion from coproduction to punish the incumbent political party, citizens' political interest and engagement in Atitlan declined. More corporatist coproduction in which migrant clubs' preferences for public goods were aligned with local government interests crowded out citizen engagement.

In cases like Atitlan, citizen exclusion from coproduction reinforced social and political inequalities in the hometown based on social mobility acquired through international migration. When paisanos positioned themselves as more knowledgeable and capable of making decisions on behalf of a town in which they no longer physically resided, this further created social division between residents and emigrants. Residents did not believe that the migratory experience had elevated 
the social status of the paisanos and they resented the implication that because they stayed in Atitlan they were more backward and incapable of selecting and advocating for projects that improved their quality of life.

Analyzing the dynamics and organizational variation of transnational coproduction partnerships through case studies illuminates how migrant HTAs' mobilization of collective remittances for hometown development has important spillover effects for democratic governance and participation. My chief purpose is to draw attention to the ways in which coproduction is configured and how different organizational forms of coproduction correspond to political outcomes in places with emigration. In doing so, I trace how community inclusion and government engagement interact at different levels to determine synergetic, corporatist, fragmented, and substitutive coproduction types. Through the cases I show how the organization of types changes as the social and political context in hometowns shape and are shaped by migrant-state interactions.

In the next chapter, I turn to a more systematic assessment of how transnational partnerships affect democratic governance and examine how generalizable the findings are across all municipalities and within only those cases that have partnerships. Using original survey data, longitudinal survey data from the Mexican Family Life Survey, and panel data on all Mexican municipalities from 1990 to 2013, I show how cumulative participation in transnational partnerships through the $3 \times 1$ Program leads to substantial effects on citizen engagement in formal and informal politics and government responsiveness. 